\title{
Extrinsic allergic alveolitis and asthma in a sawmill worker: case report and review of the literature
}

\author{
D M G Halpin, B J Graneek, M Turner-Warwick, A J Newman Taylor
}

\begin{abstract}
A 34 year old sawmill maintenance engineer developed a dry cough that was associated with widespread wheezes and crackles in his lungs. His symptoms worsened, with work related lethargy, fever, and breathlessness, and the loss of a stone in weight. At that time, while still at work, he had a neutrophil leucocytosis and increased concentration of $\gamma$ globulins. When seen subsequently some two months after stopping work, his chest radiograph and lung function tests were normal, but the cells recovered at bronchoalveolar lavage showed an increase in lymphocytes and mast cells, a pattern consistent with extrinsic allergic alveolitis. Serum precipitins were identified to extracts of sawdust, wood chips, and bark from the sawmill, and to eight species of mould grown from these samples. Specific IgG binding inhibition studies suggested that a common epitope present on Trichoderma koningii might be responsible for the cross reactivity of the patient's serum with the wood and fungal extracts. A diagnosis of wood associated extrinsic allergic alveolitis was made and since changing his job the patient has remained well. Wood associated allergic alveolitis has not previously been described in British sawmill workers, but has been reported in Sweden, with a prevalence of $5 \%-10 \%$ in exposed workers. A review of published data suggests extrinsic allergic alveolitis in wood workers is primarily caused by inhalation of the spores of contaminating fungi, but inhaled wood dust may exert a synergistic effect.
\end{abstract}

(Occup Environ Med 1994;51:160-164)

Although occupational asthma and dermatitis caused by wood and wood products are well recognised, extrinsic allergic alveolitis, or hypersensitivity pneumonitis, has been less commonly reported. Pneumonitis in workers stripping bark from maple logs was described in 1932 by Towey et al who suggested that it was caused by spores released by fungi moulding the logs. ${ }^{1}$ Subsequently, similar clinical syndromes have been described in North American woodmen and sawmill workers, Scandinavian and Canadian sawmill workers, farmers using wood chips for fuel, and Portuguese cork workers. ${ }^{2-9}$ Despite a large and active timber industry, extrinsic allergic alveolitis in woodworkers has not previously been described in the United Kingdom. We describe a sawmill maintenance engineer who developed allergic alveolitis while working in a Welsh sawmill.

\section{Case report}

A 34 year old electrical technician at a large sawmill was referred with a 12 month history of respiratory symptoms. He was well until March 1988, when at the end of a working week he had developed a persistent dry cough. Examination at that time showed widespread coarse inspiratory crackles and expiratory wheezes in his lungs. A chest radiograph was reported as normal. He was treated for a presumed infection with a broad spectrum antibiotic and remained away from work for three weeks.

On return to work he developed recurrent episodes of lethargy and feverishness that consistently occurred within one hour of finishing his work shift. On examination at that time he had a temperature of $38^{\circ} \mathrm{C}$ and fine crackles audible over both lungs. $\mathrm{He}$ remained away from work for four weeks. His symptoms resolved but again recurred on return to work. Examination at that time was unremarkable. His forced expiratory volume in one second $\left(\mathrm{FEV}_{1}\right)$ and forced vital capacity (FVC) were 3.51 and 4.01 , and his peak expiratory flow was $485 \mathrm{l} / \mathrm{min}$. He was told that he had asthma and was prescribed inhaled beclomethasone and salbutamol with some symptomatic improvement.

He returned to work, but again developed breathlessness, cough, malaise, and fever, and lost about a stone in weight. On examination he had a low grade fever and widespread inspiratory crackles over his lungs. His peripheral leucocyte count was raised at $12 \cdot 2$ $\times 10^{9} / 1$ with $76 \%$ neutrophils, his erythrocyte sedimentation rate (ESR) was $9 \mathrm{~mm} / \mathrm{h}$, and his serum $\gamma$ globulins were increased at $28 \mathrm{~g} / 1$ (normal range $7-19 \mathrm{~g} / 1$ ). He was started on a two week course of oral prednisolone and advised to remain away from work. His symptoms improved and he remained well until his return to work, when, within two days, he again developed breathlessness, cough, lethargy, and fever. On examination his temperature was $39^{\circ} \mathrm{C}$ and he again had fine crackles audible over both lungs. $\mathrm{He}$ was given another two week course of oral prednisolone and was referred for further investigation. 
At the time of admission he had been away from work for two months and had not taken prednisolone for six weeks. He was on no other medication and was free of respiratory symptoms. He had no relevant medical history and had never smoked. Physical examination was normal. His full blood count, ESR, and liver function tests were normal. His IgG was slightly increased at $19 \cdot 1 \mathrm{~g} / 1$ (normal range $6 \cdot 4-16 \mathrm{~g} / \mathrm{l}$ ), but his IgM, IgA, and $\operatorname{IgE}$ were normal. No precipitins were detected in his serum to Aspergillus fumigatus, Candida albicans, Micropolyspora faeni, Thermoactinomyces vulgaris, chicken, pigeon, or budgerigar serum. An autoantibody screen, including anti-nuclear factor and antidouble stranded DNA antibodies, was negative. Review of his original chest radiograph, reported as normal, showed bilateral ground glass shadowing.

A chest radiograph, computed tomography scan of the thorax, full lung function tests, flow-volume loop, and arterial blood gases were normal. At bronchoscopy his tracheobronchial tree was normal. The differential cell count of the cells recovered at bronchioalveolar lavage was $54 \%$ lymphocytes (mostly blast forms on microscopy), 18\% neutrophils, $26 \%$ macrophages, and $2 \%$ mast cells, a pattern characteristic of extrinsic allergic alveolitis. ${ }^{10}$

\section{OCCUPATIONAL EXPOSURE}

The patient had been employed as a maintenance electrical technician at the sawmill for three and a half years. He had previously worked as a control engineer in the Royal Navy for 12 years. His job involved working in all areas of the sawmill and occasionally he soldered, but did not associate his symptoms with this work. The sawmill processed large volumes of softwoods, predominantly spruce (Picea abies), but also Douglas fir (Pseudotsuga menziesii) and very occasionally mixed conifers, which included pine. The logs were stored for a maximum of three weeks before cutting and during this period were kept damp. The bark was stripped mechanically and immediately mulched. It was kept at the sawmill for about three days before being sold as mushroom compost or for horticultural use. The pile of mulched bark generated heat and occasionally caught fire. Wood chips and sawdust were collected from beneath the saw blades and also stored on site for about three days. The inaccessible parts of the machines were not regularly cleaned of dust and during repairs to these machines the patient was exposed to this dust.

After we saw him initially, the patient returned to work and recorded his symptoms, peak flow, and temperature. He was readmitted one month later having had recurrent fevers and highly variable peak flow recordings within five days of returning to work (fig 1). His symptoms had generally occurred shortly after returning home at the end of a shift and it seemed that he had asthma as well as systemic symptoms provoked by occupational exposure.

After undergoing the immunological studies described next, the patient was advised to change his job and has remained well without regular treatment.

\section{IMMUNOLOGICAL STUDIES}

We visited the factory but no obvious cause for his illness was identified. Samples were collected of bark strips from newly arrived logs, of mulched bark, of wood chips, of old sawdust from around the machines, and fresh sawdust from the heart of the logs. Extracts of these were made with Coca's solution $(5 \mathrm{~g}$ of sodium chloride, $2.75 \mathrm{~g}$ sodium bicarbonate, and $5 \mathrm{~g}$ phenol made up to 1 litre with distilled water). ${ }^{11}$ Immunodiffusion of these extracts against the patient's serum was carried out according to the method of Ouchterlony. ${ }^{12}$ One or more precipitin lines formed in five days between the patient's serum and all extracts. All of the samples were cultured for up to three days on Sabouraud's medium and grew Penicillium glabrum (Penicillium frequentans), Penicillium griseofulvin, Penicillium cyclopium, Rhizopus stolonifer, Aureobasidium pullulans, Mucor plumbeus, Mucor racemosus, Acremonium strictum, and unidentified yeasts. Extracts of the fungi were also prepared and double immunodiffusion performed. One precipitin line was formed between the patient's serum and extracts of Penicillium cyclopium, Aureobasidium pullulans, Rhizopus stolonifer and Acremonium strictum, and two lines formed with the extract of Mucor plumbeus. No precipitins were detected against
Figure 1 Self recorded peak flow records before and after returning to work $(\uparrow)$.

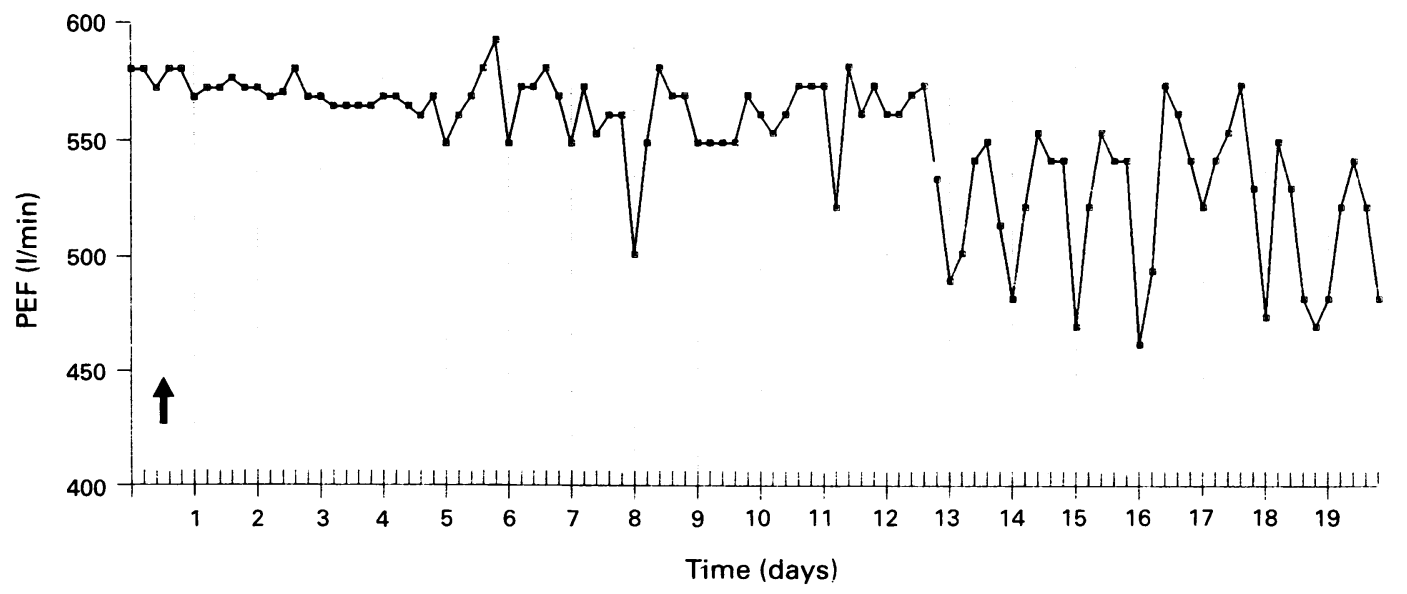


Penicillium griseofulvin, Penicillium glabrum, or Mucor racemosus.

In an attempt to characterise the epitopic specificity of the patient's immunoglobulins a series of cross inhibition radioimmunoassays were performed with protein $A$ to detect IgG1, IgG2, and IgG4. ${ }^{13}$ Although IgG was studied the principles of the assay were the same as an inhibition radioallergosorbent test (RAST) for IgE. ${ }^{14}{ }^{15}$ One hundred $\mu$ l extracts of the reference antigen diluted 1:200 in bicarbonate buffer ( $\mathrm{pH} \mathrm{9.2)} \mathrm{were} \mathrm{adsorbed}$ on to the surface of plastic microtitre plates overnight. Plates were washed three times with RAST washing buffer and the inhibition assays were conducted by placing $50 \mu \mathrm{l}$ aliquots of serial dilutions (19.5 to 5000 $\mathrm{ng} / \mathrm{ml}$ ) of each test antigen in an antigen coated microtitre well together with $50 \mu \mathrm{l}$ of the patient's serum diluted 1 in 500 with RAST buffer and $0.2 \%$ bovine serum albumin. After overnight incubation in a humid box, the wells were washed with RAST washing buffer and $50 \mu \mathrm{l}$ of $5 \mathrm{ng} / \mathrm{ml}^{125 I}$-labelled protein A (Amersham International Plc, Amersham, Bucks) were then added to each well. The plates were incubated for five hours in a humid box at room temperature and washed. The amount of protein $\mathrm{A}$ bound to the wells was measured in a gamma counter (Packard Cobra 5 Channel, Canberra Packard, Pangbourne, Berks). The amount of protein A bound to reference wells to which no competing antigen had been added or to which no coating antigen had been added was also measured.

The results were expressed as the percentage inhibition of the binding of the patient's serum and regression lines were constructed for each of the inhibiting antigens. Parallelism of these lines was taken to indicate identity of the epitope. ${ }^{16}$

These studies showed that the patient's IgG antibodies had multiple specificities against mould and wood extracts; however, there was apparent identity of an epitope on Trichoderma koningii, a wood decay fungus, and other airborne fungi isolated at the sawmill, as well as on sawdust from the

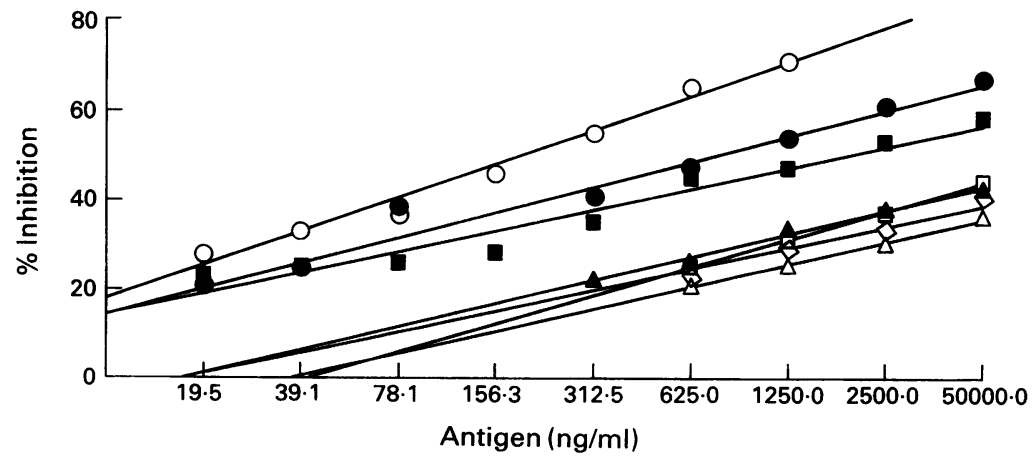

Figure 2 IgG binding inhibition studies with an extract of Trichoderma koningii (O) as the reference antigen, showing parallelism of the inhibition produced by extracts of Trichoderma pseudokoningii (O), Aurobasidium pullulans (ם), Stilbella ( $\square$ ) Aspergillus fumigatus $(\Delta)$ Penicillium glabrum $(\diamond)$, and sawdust $(\triangle)$ to that produced by Trichoderma koningii. sawmill, as shown by the parallelism of their inhibition curves (fig 2).

\section{Discussion}

Episodes of recurrent fever with breathlessness, cough, and malaise that follow a particular environmental exposure are typical of extrinsic allergic alveolitis. ${ }^{17-20}$ The broncholaveolar lavage findings in our patient, in particular the presence of mast cells and increased proportion of lymphocytes, many with the appearance of "blast" forms, are also characteristic of extrinsic allergic alveolitis. ${ }^{10}$ The lack of progression to fibrosis is atypical of extrinsic allergic alveolitis, however, and is more in keeping with a humidifier fever-like illness. Variable peak flow recordings are also not usually a feature of extrinsic allergic alveolitis, but may occur in humidifier fever; however, our patient may simply have developed asthma. The peak flow recordings showed a clear relation between variability and work, suggesting an occupational cause and wood dust is the most likely sensitising agent. The physical signs recorded in his lungs at the time of exacerbation of his illness, the abnormal chest radiograph, and the pattern of cellullar changes found at bronchoalveolar lavage suggest a peripheral respiratory reaction in addition to asthma, which was probably extrinsic allergic alveolitis. The combination of extrinsic allergic alveolitis and asthma caused by a single agent has been described $^{21}$ but is uncommon. The presence of precipitating IgG antibodies to samples of wood dusts from the patient's place of work and to some of the fungi grown from these is in keeping with extrinsic allergic alveolitis. The IgG binding inhibition studies suggest that there may be a common epitope on some of the fungi isolated at the sawmill and that there may have been colonisation of wood dust by fungi expressing this epitope, thus explaining the presence of IgG binding against wood dust and multiple fungal species.

Most previous reports of extrinsic allergic alveolitis in wood workers come from Sweden. Wood trimmers' disease occurs among workers trimming wood that has been dried in kilns, ${ }^{4}$ which are ideal incubators for moulds, the spores of which become airborne during trimming. Precipitating antibodies against Rhizopus rhizopodiformis were found in the serum samples of more than $50 \%$ of wood trimmers of whom between $10 \%$ and $20 \%$ developed symptoms suggestive of extrinsic allergic alveolitis at times of peak exposure. ${ }^{5}$

Six cases of extrinsic allergic alveolitis in sawmill workers in British Columbia have recently been reported, ${ }^{6}$ representing an estimated annual incidence of $4 \cdot 3$ per 100000 . The patients worked in coastal sawmills that cut spruce (Picea abies) and pine (Pinus sylvestris). In three cases precipitins in serum to specific fungi were found. Aspergillus was implicated in two cases and Thermoactinomyces vulgaris in one case. No cases were identified in a similar sized population of 
sawmill workers in coastal sawmills where mould resistant western red cedar (Thuja plicata) predominates.

Acute extrinsic allergic alveolitis and precipitating antibodies against fungi have also been described in Scandinavian farmers and heat plant workers who used wood chips as a fuel. ${ }^{78}$ Symptoms consistent with extrinsic allergic alveolitis in wood workers were first described in 1932 in men stripping bark from maple logs (Acer saccharum) and were due to Cryptostroma corticale. ${ }^{22}$ Individual cases with symptoms suggestive of acute extrinsic allergic alveolitis have been reported in a sawmill worker exposed to redwood (Sequoia sempervirens) sawdust ${ }^{3}$ and a woodman cutting down live oak (Quercus robustus) and maple (Acer saccharus) trees. ${ }^{2}$ Precipitating antibodies in serum were found against Graphium, Pullularia and Trichoderma species in the patient with sequoisis ${ }^{3}$ and against Penicillium species in the patient with woodman's disease. ${ }^{2}$ Two workers in the paper manufacturing industry who debarked logs have been described as having extrinsic allergic alveolitis ${ }^{23}$ and in these men inhalation challenge with an extract of Altenaria reproduced their symptoms.

Portuguese workers processing bark from the cork oak (Quercus suber) have been reported to develop extrinsic allergic alveolitis called suberosis associated with their work. ${ }^{9}$ Precipitins in serum to Penicillium glabrum have been found in up to $98 \%$ of affected workers but in only $7 \%$ of workers without disease. ${ }^{24}$

Non-occupational extrinsic allergic alveolitis associated with wood has been described in Australians living in wooden houses affected by fungi, notably Leucogyrophana pinastri. 2526

The fungi predominantly associated with extrinsic allergic alveolitis are chiefly dry spored species with spores of respirable size (less than $5 \mu \mathrm{m}$ ), which include several Aspergillus and Penicillium species. ${ }^{27}$ Less commonly slimy spored species such as Aureobasidium pullulans have been implicated; their spores become airborne in aerosols, such as those generated by humidifiers or by wet saw blades. Wood associated extrinsic allergic alveolitis may be caused by fungi of either spore type.

Wood dust itself causes asthma and may provoke immediate and late asthmatic reactions on inhalation tests ${ }^{68}$ as well as irritant and allergic dermatitis and nasal mucosal irritation. ${ }^{29}$ Some of these are due to direct toxic effects of substances within the wood dust, but allergic responses have also been identified. ${ }^{28} 29$ The role of the wood dust in the cause of extrinsic allergic alveolitis is unclear. The precipitins ascribed to extracts of wood dust, and their presence in our patient may be accounted for by immunological responses to contaminanting fungi. There is, however, evidence that the dust itself may be important. Avila and Lacey found a correlation between the prevalence of precipitins in the workforce of a Portuguese cork factory and the number of airborne cork particles, ${ }^{24}$ and wood dust particles have been seen within the granulomatous lesions in the lungs of workers with sequoisis and suberosis. ${ }^{30}$ Wood dust may persist longer in the lungs than fungal spores and may act as a carrier of fungal metabolites or hyphae and enhance the risk of sensitisation, ${ }^{24}$ provoke granuloma formation, and modify the immunological response to the fungal spores, possibly through an effect on macrophages. ${ }^{31} 32$

Although, wood associated extrinsic allergic alveolitis seems to be a rare disease, the prevalence of symptoms in heavily exposed populations, such as Swedish wood trimmers, may be between $5 \%$ and $10 \% .^{5}$ Despite an active softwood timber industry in the United Kingdom, there have been no previous reports of wood associated extrinsic allergic alveolitis. This may reflect a failure to recognise the clinical presentation, or differences in the ways in which the timber is processed. The Swedish reports emphasise the importance of the kiln as a source of mould exposure, but less than $5 \%$ of the wood at the patient's sawmill was kiln dried and there was no obvious mould growth on the kiln dried wood or in the kiln itself. The major fungal spore load at the sawmill may have come from the wood as it was debarked or from the mulched bark, in a manner analagous to the exposure in mushroom workers. ${ }^{33}$ Whatever the source of the fungal exposure, this patient shows that occupationally related extrinsic allergic alveolitis may occur in sawmill workers in the United Kingdom and further investigation is needed to investigate the specific cause.

1 Towey JW, Sweany HC, Huron WH. Severe bronchia asthma apparently due to fungal spores found in Maple bark. $\mathcal{F} A M A$ 1932;99:453-9.

2 Dykewicz MS, Laufer P, Patterson R, Roberts M, Sommers HM. Woodman's disease: hypersensitivity pneumonitis from cutting live trees. $f$ Allergy Clin Immunol 1988;81:455-60.

3 Cohen HI, Merigan TC, Kosek JC, Eldridge F. Sequoisis A granulomatous pneumonitis associated with redwood A granulomatous pneumonitis associated with

4 Wimander K, Belin L. Recognition of allergic alveolitis in the trimming department of a Swedish sawmill. the trimming department of a Swedish sawmill.

5 Belin L. Sawmill alveolitis in Sweden. Int Arch Allergy Appl Immunol 1987;82:440-3.

6 Enarson DA, Chan-Yeung M. Characterisation of health effects of wood dust exposures. Am F Ind Med 1990;17 33-38.

7 van Assendelft AHW, Raitio M, Turkia V. Fuel chipinduced hypersensitivity pneumonitis caused by penicillium species. Chest 1985;87:394-6.

8 Kolmodin-Hedman B, Blomquist G, Lofgren F. Chipped wood as a source of mould exposure. European fourmal of Respiratory Diseases 1987;71(suppl154):44-51.

9 Avila R, Villar TG. Suberosis. Respiratory disease in cork workers. Lancet 1968;i:620-1.

10 Haslam PL, Dewar A, Butchers P, Pimett ZS, NewmanTaylor A, Turner-Warwick M. Mast cells, atypical lymphocytes and neutrophils in bronchoalveolar lavage in phocytes and neutrophils in bronchoalveolar lavage in extrinsic alle

11 Tee RD, Gordon DJ, Hawkins ER, Nunn AJ, Lacey J, Venables KM, et al. Occupational allergy to locusts: an investigation of the sources of the allergen. $\mathcal{F}$ Allergy Clin Immunol 1988;81:517-25.

12 Ouchterlony $O$. Antigen-antibody reactions in gels; types of reaction in coordinated systems of diffusion. Acta Path Microbiol Scand 1953;32:231-40.

13 Langone JJ, Boyle MDP, Borsos T. ${ }^{125}$ I Protein A: application to the quantitative determination of fluid phase and cell-bound IgG. I Immunol Methods 1977;18:281-93.

14 Gleich GJ, Larson JB, Jones RT, Baer H. Measuremen of the potency of allergy extracts by their inhibitory 
capacities in the p73 radioallergosorbent test. $\mathcal{F}$ Allergy Clin Immunol 1974;53:158-69.

15 Karr RM, Wilson MR, Anicetti VR, Leher SB, Buthcher BT, Salvaggio JE. An approach to fungal antigen relationships by radioallergosorbent test inhibition. $\mathcal{F}$ Allergy Clin Immunol 1981;67:194-8.

16 Bolton AE, Hunter WM. Radioimmunoassay and related methods. In: Weir DM, Herzenberg LA, Blackwell C methods. In: Weir DM, Herzenberg LA, Blackwell C, Herzenberg LA, eds. Handbook of experimental immunology. Vol 1. Immunochemistry. 4th ed.
Scientific Publications, 1986;26:1-56.

17 Salvaggio JE. Hypersensitivity pneumonitis; state of the art. Chest 1979;75:270-6.

18 Fink JN. Hypersensitivity pneumonitis. f Allergy Clin Immunol 1984;74:1-9.

19 Grant IWB. Extrinsic allergic alveolitis (the hypersensitivity pneumonitides) In: Kay AB, Geotzl EJ, ed. Current perspectives in the immunology of respiratory disease. Edinburgh: Churchill Livingstone 1985;38-55.

20 Parkes WR. Occupational lung diseases. 2nd ed. London Butterworth, 1982:359-72.

21 O'Brien IM, Bull J, Creamer B, Sepulveda R, Harries M, Burge PS, Pepys J. Asthma and extrinsic allergic alveolitis due to Merulius lachrymans. Clinical Allergy

22 Wenzel FJ, Emanuel DA. The epidemiology of Maple bark disease. Arch Environ Health 1967;14:385-9.

23 Schlueter DP, Fink JN, Hensley GT. Wood-pulp workers' disease: a hypersensitivity pneumonitis caused by Alternaria. Ann Intern Med 1972;77:907-14.
24 Avilia R, Lacey J. The role of Penicillium frequentans in suberosis (respiratory disease in workers in the cork industry). Clinical Allergy 1974;4:109-17.

25 Stone CA, Johnson GC, Thornton JD, Macauley BJ, Holmes PW, Tai EH. Leucogyrophana pinastri, a wood decay fungus as a probable cause of an extrinsic allergic alveolitis syndrome. Aust $N Z$ Z Med 1989;19:727-9.

26 Bryant DH, Rogers P. Allergic alveolitis due to wood-rot Bryant DH, Rogers P. Allergic alvedit Allergy Proc 1991;12:89-94.
fungi

27 Lacey J, Crook B. Fungal and actinomycete spores as pollutants of the workplace and occupational allergens.
lacen Ann Occup Hyg 1988;32:515-33.

28 Chan-Yeung M, Lam S. Occupational Asthma. Am Rev Respir Dis 1986;133:686-703.

29 Woods B, Calnan CD. Toxic woods. $\mathrm{Br} f$ Dermatol 1976;95(suppl 13):1-97.

30 Pimentel JC, Avilia R. Respiratory disease in workers in the cork industry (suberosis): new trends and diagnostic possibilities. Thorax 1973;28:409-23.

31 Seal RMF, Edwards JH, Hayes $M$. The response of the lung to inhaled antigens. Progress in Respiratory Diseases 1975;8:125-9.

32 Zaidi SH, Dogra RKS, Shankter R, Chaudra SV. Experimental farmer's lung in Guinea pigs. $\exists$ Pathol Experimental farm

33 Lacey J. Hazards to health from airborne spores in the mushroom industry. In: Griffiths WD, ed. Aerosols: their generation, behaviour and application. Aerosol Society second conference. London, Aerosol Society, 1988;89-94.

\section{Destruction of manuscripts}

From 1 July 1985 articles submitted for publication will not be returned. Authors whose papers are rejected will be advised of the decision and the manuscripts will be kept under security for three months to deal with any inquiries and then destroyed. 